\title{
H1-7 wt Allele
}

National Cancer Institute

\section{Source}

National Cancer Institute. H1-7 wt Allele. NCI Thesaurus. Code C162800.

Human H1-7 wild-type allele is located in the vicinity of $12 \mathrm{q} 13.11$ and is approximately 1 $\mathrm{kb}$ in length. This allele, which encodes testis-specific $\mathrm{H} 1$ histone protein, plays a role in chromosome condensation during spermatozoa maturation. 